\title{
Land, development and the irrationality of international law
}

\author{
Pål Wrange
}

Forthcoming in Scandinavian Studies in International Law, vol 60: Law and development, (2015)

\section{Introduction}

\section{A woman in Uganda}

Imagine a women named Flora Alanyo. She lives in a shed at the outskirts of Gulu town in Acholiland in Northern Uganda, with her four children, 10, 12, 13 and 15. Flora used to live in the village of Lakang, almost $100 \mathrm{~km}$ to the west of Gulu, with her husband, William Okum. During the war between the government and the LRA rebels, they had to flee twice, until, in 2002, the government ordered everyone to settle in so-called protected villages. William died in 2004, at the hands of the Ugandan Army (the UPDF), when he was trying to look after his fields, in violation of a curfew.

Flora, who comes from a different clan than her husband, had married to William in 1998. Luckily, she was allowed to go back to Lakang, when the IDP camp was closed in 2008, although many other widows had been driven away under similar circumstances. While William's plot had been taken over by his brother, Flora was referred by the elders to go further out and find land, which had previously been used for grazing.

The land that Flora found for herself has not been titled. It is customary land. According to the government (and its District Land Board), it is government land. While the brother-in-law had secured a registered title of ownership over what used to be William's and Flora's plot, she had not had sufficient funds to go through that process. In 2012 the Government leased a large swathe of "unregistered" land, including Flora's, to a British investor, for the purpose of 
sugarcane farming. The investor was anxious to "get the squatters off my land", and with the help of the UPDF, Flora and others were soon evicted. She went to find a living in the closest town.

Flora turned to the authorities to get her land back, but to no avail. In the local court, it was explained that the government owned the land, and that the deal was protected both by an investment treaty and by a concession contract, the latter one being enforceable under Ugandan law. In an obiter dictum, the judge told her that even if it had not been the Government's land, it belonged to the clan, and she was no longer a member of the clan, since her husband had died.

This situation is not authentic, but it could have been. Against the backdrop of the fate of many war widows in Northern Uganda, it is specifically inspired by two cases of alleged "land grab" in Uganda: the Amuru Sugar Works case and the Kaweri Coffee Plantation case, to which I will return later. ${ }^{1}$ I have amalgamated the two in order to provide a focus for my question: If international law cannot help Flora, what is wrong with international law?

\section{International Land Law - an irrational hodgepodge.}

The purpose of law is to regulate human activity and to settle disputes in an efficient and rational manner, that is, to get outcomes that correspond to a certain (and presumably coherent) conception of justice, what Ronald Dworkin calls integrity. ${ }^{2}$ Domestic law sometimes does this, and sometimes not. However, to the extent that domestic law fails in this respect, it can be fixed by a legislator, or by a supreme court, which balances different interests. ${ }^{3}$

At the international level it is different. If there is a problem with the law, it takes agreement, or at least tacit acquiescence, between some 200 states to have it fixed. If powerful interests are vested in an irrational status quo, the prospects for change are bleak.

And yet, people are justified in expecting integrity from international law. In the preamble to the UN Charter, states declare that they are "determined to save succeeding generations from the scourge of war ... to reaffirm faith in fundamental human rights, in the dignity and worth of the human person, in the

\footnotetext{
1 My reason for choosing Uganda, is biographical: I lived there for three years.

2 Dworkin, Ronald, Law's Empire, Harvard University Press, 1986, p. 176. See also Franck, Thomas, Fairness in International Law and Institutions, Clarendon Press, Oxford, 1995, p. 7-8.

${ }^{3}$ In domestic law, land is regulated by a fairly coherent set of norms, like a land code. Other norms which relate to land (for instance bankruptcy law or criminal law) may have different purposes than land law in a strict sense, but those other norms will be drafted so as to take land law into account. Hence, the risk of major dysfunctionality is limited.
} 
equal rights of men and women and of nations large and small, and to establish conditions under which justice and respect for the obligations arising from treaties and other sources of international law can be maintained, and to promote social progress and better standards of life in larger freedom." In Article 28 of the Universal Declaration of Human Rights, states proclaim that "[e]veryone is entitled to a social and international order in which the rights and freedoms set forth in this Declaration can be fully realized." In the Outcome document of the 2005 World Summit - the latest global summit - the leaders of the world reaffirmed their "common fundamental values, including freedom, equality, solidarity, tolerance, respect for all human rights, respect for nature and shared responsibility" and acknowledged that, "peace and security, development and human rights are ... the foundations for collective security and well-being". ${ }^{4}$ Hence, one would assume that international law is rational from the perspective of these values, of which human rights are central.

Even if it is impossible to conclusively determine that one course of action is more rational than another, I still believe that the basic idea of rationality is useful. ${ }^{5} \mathrm{By}$ rationality I here mean that the likely outcome of a regulation (or an aggregate of regulations) should be reasonably in line with the aggregate will of the parties involved guided by a common conception of justice. ${ }^{6}$ The parties involved are states as the makers of international law, and the intention can be gleaned from solemn declarations such as the ones quoted above. ${ }^{7}$ As will become clear during the course of this essay, it is not necessary for the present purpose to clarify the complex idea of rationality any further. ${ }^{8}$

International law regulates things of international concern, which seems to include land. After all, as John Locke explained, all wealth comes from the mixing

${ }^{4}$ UN General Assembly Resolution A/RES/60/1, paras 4 and 9.

5 Such critique has been levelled by, for instance, the Frankfurt school and a number of other currents of thought in the 20th century. For a nuanced discussion of rationality, integrity and law, see Habermas, Jürgen, Faktizität und Geltung - Beiträge zur Diskurstheorie des Rechts und des demokratischen Rechtsstaats, Suhrkamp, 1992 p. 242-272.

6 This means for the purpose of my argument, ns of the negotiators but the aggregate will of all the parties involved if they had been fully informed of the negotiations and of the global effect of the proposed regulation. As I will discuss below, an important problem in international law is the fragmentation of the law and the sectorial character of rule-making. ${ }^{7}$ I believe that such declarations are much more relevant than for instance preambles to bilateral investment treaties (BITs). Solemn declarations like the Summit Outcome document are issued at the highest level of government under consideration of the collected interests of the parties involved - and of the international community. By contrast, BITs are drafted and undertaken from sectoral interests.

8 The irrationality of the aggregate international regulation in question here will be beyond doubt: It could not reasonably have been the purpose of international law that a widow's access to land should be trumped by the rights of a multinational corporation. 
of labour with land. International law already has quite a lot to say about the use of land -- human rights to property, housing and access to food, and principles and agreements that protect foreign investments (see below) - and one would believe that that intervention should be coherent. ${ }^{9}$ However, while there is international law pertaining to the seas and space, there is no international land law, and certainly not much coherence, as I will show. ${ }^{10}$

In this essay I will look at the international rules relevant to the use of land and see whether they are rational from the point of view of the noble declarations cited above. I will first outline some ways to think about land. Thereafter, I will discuss types of domestic and international regulation of land, and I will take Northern Uganda as my example. In the end, I will find that international law protects one form of rights and one type of rights-holder (investments and investors) over other rights and rightsholders (land rights of peasant women), and that it is difficult to justify this discrepancy based on any generally accepted values and principles.

\title{
Ways of, and reasons for, the regulation of the use of land
}

\author{
Land can be regulated by many normative systems at different levels with \\ different rationals, and different people think that different characteristics can
}

\footnotetext{
${ }^{9}$ It therefore seems reasonable to analyze international law from the particular perspective of land When a new field of law is developed, that is because a group of people decide to look at law from a new point of view. A legislator wants to create a code for a particular area (commercial transactions, real estate, penal law etc). A scholar wants to analyze legal provisions relating to a certain field or problem (children, IT etc). If the scholar's perspective turns out to be fruitful, it will become accepted, and more people will start to analyze the law from that perspective, and discover features which are irrational from that point of view.

10 I found only one genuine reference to "international land law" on the Internet. Under the rubric "international land law", a law firm explained that "[ $t$ ] he lack of well-defined real estate rights and their registration in dedicated land registries serves as an obstacle of transforming planned economies to market oriented ones. The firm ... has rendered advice in numerous donor funded projects on land and land registration law in former Soviet Union countries." http://www.sar-law.com/index.asp?id=1078.

Many areas of domestic law have been developed into areas of international law - think of now well established fields like international environmental law, international criminal law, international criminal procedural law, and even international private law. These fields have been developed, because there was a need for it. The former absence of these fields did not entail that the issue areas concerned were not regulated. In fact, they were. There were rules applicable to environmentally bad activities - sovereignty, sic utere etc. But there was no telos, no rules that made the abstract principles of sic utere efficient to the may different ways that the environment can be harmed, and no rules that took care of the common interest in a clean atmosphere or straddling fish stocks.

Many issues usually covered by domestic land law -- such as the details of the formal requirements for transactions in real estate and the use of land as security for credits -- are probably dealt with better at that level. However, given the importance of land, existing international regulations pertaining to land should be analyzed with a view to potential reform from the perspective of land law.
} 
form the basis for land claims. ${ }^{11}$ In most regulations relevant to this article, land is thought of as an economic asset which can be a source of wealth, through the subsoil, minerals, vegetation, grazing rights and built structures, or as security for credits. ${ }^{12}$ However, land can also be tied to a whole life-form; as Kindi explains, "for most people land represents home, binds together past, present and future and constitutes people's spiritual base." ${ }^{13}$ Land may also represent the bases for political power, for whoever controls it. ${ }^{14}$

As suggested by these varied uses and functions of land, there are different potential types of rights related to land, such as the right to prescribe the use of land (which is usually a public function); the right to use land for different economic purposes (cultivation, grazing, mineral extraction etc) which may be exclusive or joint, and even seasonal; the right to benefit from the proceeds (or use) of land; the right to dispose of land through sale, inheritance etc; and the rights to other forms of use, such as the rights to live on the land, to use it for communication or for religious purposes. ${ }^{15}$

These various rights are distributed in different forms in different parts of the world and private ownership is only one such form: ${ }^{16}$ no property rights (open access); terra nullius, open for appropriation; communal property (of a tribe, a clan, a village, a city etc), with different forms of user rights apportioned amongst its members; crown land (perhaps a variety of communal property); and private property. ${ }^{17}$ Property rights can be individualized or collective. In traditional

\footnotetext{
${ }^{11}$ See, for instance, Hurwitz, Agnès, Studdard, Kaysie and Williams, Rhodri C, Housing, land property and conflict management: identifying policy options for rule of law programming, International Peace Academy, 2005, p. 5, http://2001-2009.state.gov/documents/organization/98035.pdf.

${ }^{12}$ On commoditization, see Appadurai, Arjun, The Future as Cultural Fact: Essays on the Global Conditio, Verso, 2013, p. 21-23.

${ }^{13}$ Kindi, Fredrick Immanuel. Challenges and Opportunities for Women's Land Rights in Post-Conflict Northern Uganda, Microcon Research Working Paper 26, 2010, p. 21, http://www.microconflict.eu/publications/RWP26_KFI.pdf.

${ }_{14}$ Therefore, as Hurwitz et al note, "land conflicts may be interwoven with broader competition for political dominance." Hurwitz et al, note 10, p. 5. See also Uganda Land Alliance, Land Grabbing and its Effects on the Communities in the Oil Rich Albertine Region of Uganda: The Case of Hoima, Buliisa and Amuru, Kampala, 2011, p. 1, www.ualug.org. See also Sjögren, Anders, Scrambling for the promised land: land acquisitions and the politics of representation in post-war Acholi, northern Uganda, African Identities, vol. 12, 2014, pp. 62-75, at p. 64.

${ }^{15}$ Cf Feder, Gershon, and Noronha, Raymond, Land rights systems and agricultural development in Sub-Saharan Africa, The World Bank Research Observer, vol 2, 1987, p. 143 at p. 153.

${ }^{16}$ Cf Feder, Gershon, and Feeny, David, Land tenure and property rights: theory and implications for development policy, The World Bank Economic Review, vol 5 (1991), p. 135-153, at p. 137,

http://wber.oxfordjournals.org/content/5/1/135.short.

17 As the EU Task Force on Land Tenure concludes:

Land rights are not limited to private ownership in the strict sense, but can be a very diverse balance between individual rights and duties, and collective regulations, at different levels (different levels of family organisation, communities, local governments or state), private or family ownership being
} 
societies the group (family, clan) is often more important than the individual and may make claims as collectives. ${ }^{18}$

Property can be distributed according to any of a number of different principles. Philosophers distinguish between various doctrines of distributive justice: Egalitarianism, which means that everyone should have the same resources, as a starting point and/or as a final result; the difference principle, which means that inequalities shall be allowed as long as those least advantaged are better off; equality of opportunity principles; welfare based (or utilitarian) principles; distribution according to desert, which means that wealth should be distributed in accordance with norms that reward certain types of behavior, like hard work; ${ }^{19}$ and libertarian principles, which entail that the existing distribution should not be interfered with at all. In addition to the principles of distribution, there are principles of commutative justice, which concern all forms of transactions between persons, from private contracts to crimes. Commutative justice may require a fair price in a contract or compensation in a tort case. In addition there may be traditional principles of distributing land and other resources which may build on similar ideas or on other ideas.

The point here is that there are a number of different ways of distributing land, grounded in different ideas about what land is good for and based on different normative systems ${ }^{20}$ and conceptions of justice, and that it is not at all self-evident which is the right one in a particular situation, and even less that there is one regime that is right for all situations. ${ }^{21}$ As we will see, international law recognizes a broad scope of land rights, based on different principles, but

one possible case. The rights and duties that individuals or a family hold are themselves embedded in a set of rules and norms, defined and enforced by authorities and institutions which may be those of rural communities and/or of the state.

EU Task Force on Land Tenure, EU Land Policy Guidelines: Guidelines for support to land policy design and land policy reform. 2004, p. 7.

${ }^{18}$ For instance, the Acholi tribe in war-torn Northern Uganda have a plausible claim that they have been discriminated and marginalized. Such collectivised grievances are, in a sense, imposed on the Acholi from outside actors who have identified the Acholi as a group that needs to be treated differently, but that does not make the claim any less real. However, one should not make too much of a difference between the traditional and the modern: in traditional societies, there are many people who do not accept that their claims are taken over by a group, and there are many collective claims in modern law as well (corporations, organizations etc).

19 Lamont, Julian and Favor, Christi, Distributive Justice, in Stanford Encyclopedia of Philosophy, 2013, http://plato.stanford.edu/entries/justice-distributive/. Atuahene notes the important role of desert. Atuahene, Bernadette, Things Fall Apart: The Illegitimacy of Property Rights in the Context of Past Property Theft, Arizona Law Review, vol 51, 2009, p. 829, at p. 833.

20 EU Task Force on Land Tenure, note 16, p. 6.

${ }^{21}$ Cf Easterly, William, The white man's burden: why the West's efforts to aid the rest have done so much ill and so little good, Penguin, 2006. 
gives much stronger protection to some than to others. What does this mean for Flora? But first we will take a regional and a national perspective.

\section{The treatment of land in Uganda and other African societies}

\section{African land and development}

Before colonialism, African land was distributed according to various traditional principles, most of them involving what we might call communal ownership, but with private user rights. Land rights were generally split between individuals, the family and the community (the village, the clan), and the individual was not entitled to sell or give away the land without permission, at least not to parties outside the community. ${ }^{22}$ Customary law was not always egalitarian and far from always gender neutral, but in general it ensured that every member of each respective community had enough land to survive.

It is difficult to categorize the rights of the various parties involved - communal ownership with individual user rights or individual ownership under communal/public regulation, or perhaps open access. ${ }^{23}$ This conceptual difficulty presented itself to the colonialists, who interpreted the prevailing orders in different ways when they tried to translate them into their acquired ways of thinking. Focusing on the British colonies (Uganda being a former one), we find that the British (mis)conceptions - bona fide or not - had two effects which were beneficial to the colonialists and devastating to the traditional organization of land. First, the British distinguished between occupied and unoccupied lands, the latter of which were vacant and therefore open to settlement. ${ }^{24}$ (In fact, much of the "unoccupied" land was used as hunting or grazing ground or was subject to shifting cultivation. ${ }^{25}$ ) Second, they held that all occupied "native" land was held in "communal tenure," exercised by chiefs as "trustees for existing and future generations." ${ }^{26}$ Hence, the status of chiefs was elevated, and where the traditional organization did not correspond to the British conception of tribes, new chiefs and kings were appointed. ${ }^{27}$ This made colonial administration simpler, but it also disempowered commoners in many places where the chief

\footnotetext{
${ }^{22}$ Feeder and Feeny, note 15, p. 138; Migot-Adholla, Shern et al. Indigenous land rights systems in sub-Saharan Africa: a constraint on productivity?, The World Bank Economic Review, vol 5, 1991, p. 155-175, at p. 159. Hence, individual land rights were often transitory and subject to group control, but could also approach private ownership. See Feder and Noronha, note 15, p. 143 and 163.

${ }^{23}$ Migot-Adholla et al, note 21, at p. 159.

${ }^{24}$ Feder and Noronha, note 15, p. 142.

${ }^{25}$ Feder and Noronha, note 15,p. 148.

${ }^{26}$ Feder and Noronha, note 15, p. 148.

${ }^{27}$ Feder and Noronha, note 15, p. 149.
} 
had previously been a primus inter pares rather than an anointed agent of God (or the Queen).

Hence, with the exception of titling and freehold rights for colonial settlers, the property regimes were generally left intact, though perverted. ${ }^{28}$ In Uganda, most land was declared "crown land", although customary occupants could generally remain on the land. ${ }^{29} \mathrm{~A}$ land reform to introduce private ownership was commenced by the British but was far from completed when Uganda gained independence in $1962 .{ }^{30}$

Consequently, Uganda, like many other newly independent African states, started out with government ownership of large parts of the land - "inherited" from the colonial power. ${ }^{31}$ Many African countries just retained the colonial regulation of real estate, ${ }^{32}$ while others went further and expropriated all land, as was the case in Uganda in 1975 during Idi Amin, ${ }^{33}$ and yet a few others have fully recognized customary tenure. Hence, there is a wide difference in approaches between African countries that allow individual title, countries that recognize different kinds of tenure and countries where the state owns all land. ${ }^{34}$ During the first years of independence, the dominant socio-economic doctrine was that of development or modernization. ${ }^{35}$ There were both liberal and more left-leaning strands of this line of thinking, but the main implementation strategy was one of import-substitution. During this period there were some efforts of land reform, but the focus was generally on industrialization. In line with the

\footnotetext{
${ }_{28}$ Migot-Adholla et al, note 21, 158. The problem was, though, as indicated, that the "customary regimes of land tenure were almost uniformly subordinated to imported European-derived systems." Wily, Liz Alden, Tackling land tenure in the emergency to development transition in post-conflict states: From restitution to reform, in Pantuliano, Sara (ed.), Uncharted territory: Land, Conflict and Humanitarian Action, Practical Action Publishing, Warwickshire, 2009, p. 27-50, at p. 36.

${ }^{29}$ Mugambwa, John, A comparative analysis of land tenure law reform in Uganda and Papua New Guinea, Journal of South Pacific Law, vol 11, 2007, p. 39-55, at p. 40; Uganda Land Alliance, note 14, p. 5.

${ }^{30}$ Mugambwa, note 29, p. 41

31 Wily, note 28, p. 36.

32 Mugambwa, note 29, p. 42-43; Huggins, Chris, Linking broad constellations of ideas: Transitional justice, land tenure reform, and development, International Center for Transitional Justice, 2009, p. 2, https://www.ictj.org/sites/default/files/ICTJ-Development-LandTenureReform-ResearchBrief-2009-English.p df.

33 Mugambwa, note 29, p. 44.

${ }^{34}$ Feder and Noronha, note 15, p. 150.

35 This and the next few paragraphs are in general - but not completely -- based on de Vylder, Stefan, Utvecklingens Drivkrafter, 2nd edn, Forum Syd, Stockholm, 2007, p. 22-56. See also Sarkar R, International Development Law: Rule of Law, Human Rights, and Global Finance, Oxford University Press, 2009, p. 46 et seq; Bernstein, Henry, Land Reform: Taking a Long(er) View, Journal of Agrarian Change, vol. 2, 2002, p. 433, at p. 442.
} 
subsequent efforts to introduce a New International Economic Order, ${ }^{36}$ the respect for foreign investment was generally low. Then, in the 1980's, when it was (rightly or wrongly) concluded that the earlier state-driven policies had failed, there was a general turn to the market. The Washington consensus, formed between the World Bank, the IMF and US Government agencies, called for macroeconomic stability and structural reforms, and put an emphasis on market principles - applicable in developed as well as in developing states. ${ }^{37}$ Law and economy, influenced by neo-liberal doctrines, suggested that private ownership was better than communal, and some communal land was subjected to registration. As some have noted, there was a shift from land reform to land law reform. ${ }^{38}$ This was further reinforced by the teachings of the influential economist Hernando de Soto, who suggested that international institutions should promote registration and titling. ${ }^{39}$ Although the Washington consensus is no longer dominating, foreign investment is still widely held to be beneficial, albeit with greater account for local variations and for social concerns. Since most land in Africa is not titled, or is designated public land, willing governments have been able to control if not own land and make it available for lease (most

\footnotetext{
36 See the Declaration on the Establishment of a New International Economic Order, UNGA Resolution 3201 (S-VI). See also Kennedy David, The' Rule of Law,' Political Choices, and Development Common Sense, in Trubek, David M and Santos, Alvaro (eds), The New Law and Development, Cambridge University Press, 2006, p. 95, at p. 110-128.

37 See Bernstein, Henry, Land Reform: Taking a Long(er) View, Journal of Agrarian Change, vol. 2, 2002, p. 433, at p. 445; Rajagopal, Balakrishnan. Counter-hegemonic International Law: rethinking human rights and development as a Third World strategy, Third World Quarterly vol 27, 2006, p. 767, at p. 777; de Vylder, note 35, p. 33-40; Kennedy, note 36, p. 128-150.

38 Assies, Willem, Land Tenure, Land Law and Development: Some Thoughts on Recent Debates, Journal of Peasant Studies vol 36, 2009, p. 573-589, at p. 585.

${ }^{39}$ De Schutter, Olivier, Report of the Special Rapporteur on the Right to Food, United Nations Human Rights Council, A /65/281, 2010, 10 [cit De Schutter 2010]. de Soto's most famous work is The Mystery of Capital: Why Capitalism Triumphs in the West and Fails Everywhere Else, Basic Books, New York, 2000.

His teachings are not undisputed, though. While some argue that individual ownership provides an important incentive to productive investment, others claim that customary arrangements - which protect small-scale farmers -- may be more efficient, and that customs may evolve to take account of developments. See Migot-Adholla et al, note 21, p. 170-171; Feder and Noronha, note 15, p. 163; Huggins, note 32, p. 2; Burg, Elliot M., Law and Development: A Review of the Literature \& a Critique of "Scholars in Self-Estrangement", The American Journal of Comparative Law, vol 25, 2013, p. 492-530, at p. 525. One study, published by the World Bank, finds that there is "no relationship between cross-sectional variations in land rights and productivity" Migot-Adholla et al, note 21, p. 154, at p. 172. See also De Schutter 2010, note 39, p. 10. Some writers find that security of tenure is more important than formal ownership. Mamdani, Mahmood, The Contemporary Ugandan Discourse on Customary Tenure: Some Theoretical Considerations. MISR Working Papers No. 13, Kampala, 2013, p. 3), whereas others find that neither security nor formal registration is crucial (Ravnborg, Helle Munk, Bashaasha, Bernard, Hundsbæk Pedersen, Rasmus, Spichiger, Rachel and Turinawe. Flora, Land Tenure under Transition - Tenure Security, Land Institutions and Economic Activity in Uganda, DIIS Working Paper 2013:03, p. 68.
} 
commonly) or purchase. ${ }^{40}$

This is not the place to determine the merits of the various property rights schemes practiced through African history. It is, however, important to note that any titling, including titling of traditional land, affects rights. Titles often imply ownership rather than traditional user's rights, which may upset traditional arrangements. Titling may also solidify an unequal distribution of land, created by political, economic or social forces, historical or contemporary. ${ }^{41}$

\section{The regulation of land in Uganda}

Like many African countries, customary regulation of land prevails in most parts of Uganda. Before the implementation of the 1995 Constitution through the 1998 Land Act, ${ }^{42}$ Ugandan law did not formally recognize customary tenure although it often prevailed in practice -- and all land was vested in the state through the Uganda Land Commission. ${ }^{43}$ However, Article 237 of the 1995 constitution recognized customary tenure as one of four ways of ownership of land, ${ }^{44}$ further providing that "all Uganda citizens owning land under customary tenure may acquire certificates of ownership" and that "land under customary tenure may be converted to freehold land ownership by registration". ${ }^{45}$ As noted by Mamdani, the implementing land law is ambiguous with two, potentially contradictory, purposes - greater security of tenure and the development of a land market. ${ }^{46}$ It is relevant to note that Article 26 of the Constitution provides for protection from deprivation of property, which is broadly in line with international standards for human rights and for investment protection (see Section 4).

Although there is also state-owned land and land that is owned or leased by

\footnotetext{
${ }^{40}$ Foreign acquisition of land in Africa (including Uganda) generally takes the form of lease, due to common constitutional restrictions on ownership of real estate by foreigners.

${ }^{41}$ See De Schutter 2010, note 39, p. 10.

${ }_{42}$ Cap 227. The Act is available at http://www.ulii.org/ug/legislation/consolidated-act/227.

${ }^{43}$ Mabikke, Samuel B, Escalating Land Grabbing In Post-conflict Regions of Northern Uganda : A Need for Strengthening Good Land Governance in Acholi Region, Land Deal Politics Initiative, 2011, p. 8, www.future-agricultures.org.

${ }_{44}$ The others are freehold, mailo (a particular form of ownership practiced in Uganda as a result of an agreement between the British and the king of Buganda in 1900) and leasehold. See generally, Mugambwa, note 29 , p. 52.

${ }^{45}$ This was developed in Sections 4 and 9 of the Land Act, which also provided that groups or communities can form communal land associations (Section 15). According to one study, "permission to change should be granted as long as the customary law of the community concerned recognises or provides for individual ownership." Mugambwa, note 29, p. 53.

${ }^{46}$ Mamdani, note 39, p. 9; Sjögren, note 14, p. 67.
} 
investors, customary land regimes dominate in Northern Uganda, ${ }^{47}$ and most land in this region is not registered. Disputes can be settled both by formal and informal (customary) means - each with its merits and drawbacks -- and often the two systems do not function in harmony with one another. ${ }^{48}$ These problems have been exacerbated by the war (see below). ${ }^{49}$

One particularly important aspect of this complexity needs to be mentioned, namely the position of women. In traditional Acholi culture, sons who were ready to marry were given a piece of land. However, this practice assumed three principles: Everyone is entitled to land; all inherited land is family land; and selling requires approval by the clan, premised on the ability to provide for children in the family and agreement of the whole family. ${ }^{50}$ Hence, as Adoko summarizes, "all women are guaranteed land rights" -- single women from their parents, married women through their husbands, and widows by becoming heads of their families. ${ }^{51}$ However, the position of women in the North has been affected by the breakdown of traditional structures during the civil war as well as the commodification of land, where male guardianship of family land sometimes gets confused with male private ownership. ${ }^{52}$

Women have received further protection in the Land Act, including the requirements that transactions involving family land must have the consent of women (Sec 39) and that decisions respecting customary land must not be discriminatory against women (Sec 27). ${ }^{53}$ However, due to the patriarchal nature

\footnotetext{
47 As suggested above, the customary rights in this part of Uganda have been characterized differently by different observers, and cannot easily be translated into Western terminology. For two conflicting assessments, see Mabikke, note 43, p. 22;. Kindi, note 12, p. 24. It is not necessary for the purpose of this essay to determine how to rightly characterise these various rights.

${ }^{48}$ International Alert, Monitoring the impact of the Peace, Recovery and Development Plan on peace and conflict in Acholi and Lango 2011-2012, 2013, p. 8, http://www.international-alert.org/sites/default/files/Uganda PRDPAcholiLango EN 2013.pdf.

${ }_{49}$ See Kindi, note 12, p. 9; Sjögren, note 14, p. 68; Mamdani, note 39, p. 5; MercyCorps, Land Disputes in Acholiland, 2011, p. 7,

http://www.international-alert.org/sites/default/files/Uganda PRDPAcholiLango EN 2013.pdf.

${ }^{50}$ Adoko, Judy, How Does Land Grabbing Happen: Experiences from Northern Uganda?, Land and Equity Movement in Uganda, 2008, p. 7.

${ }^{51}$ Adoko, note 50, p. 7-8. See also Kindi, note 12, p. 16. Adoko finds that "[t]he protection given to the land rights of women, orphans and any other vulnerable groups in Northern and Eastern Uganda is probably as good as can be found anywhere in the world." Adoko, p. 7.

${ }^{52}$ In this region more than $30 \%$ of the households are headed by women, who along with children have difficulty in accessing land. Kindi, note 12, p. 21.

${ }^{53}$ There are also requirements of increased participation of women in the various governmental organs involved. The Uganda Land Commission shall have at least one women out of its five members, one third of the membership of the district Land Board shall be female, and there should be at least one woman out of four members of the land committees at the parish level. See also Kindi, note 12, p. 12.
} 
of Northern Uganda, it has been difficult to implement it. ${ }^{54}$ The Uganda Land Policy, adopted in 2013, states that there is a need to mainstream gender into development planning. Further, the Government should design a regime of matrimonial property that protects spouses both within and outside marriages and women's inheritance of land shall be promoted. ${ }^{55}$ The policy also aims to increase the protection of customary rights, but on conditions. "[T]he rules of transmission of land rights under customary land tenure [shall] guarantee gender equality and equity" and "[m]ake provision for joint ownership of family land by spouses". Amendments to the land act must also clearly distinguish customary family rights, individual rights and communal rights and safeguard the role of traditional institutions. ${ }^{56}$

The land policy recognizes the potential problems associated with commercial investments. The government shall "[p]rotect the land rights, including rights of citizens in the face of investments with ... [c]lear procedures and standards for local consultation" and "[m]echanisms for appeal and arbitration". ${ }^{57}$ At the same time, the government is also keen on promoting investment, and the World Bank and other international actors emphasize "that access to land is very important for investments". 58

In Northern Uganda, existing problems related to land were greatly exacerbated by the two-decades long civil war between the Government of Uganda and the Lord's Resistance Army (LRA), which affected millions of people, and in particular inhabitants of Acholiland - which was both the breeding ground for and the primary target of the LRA. According to credible estimates, $78 \%$ of a population which depended on subsistence farming were forced to leave their land or were unable to access it, because of orders of the UPDF (the Ugandan Army) or due to the threat of violence from the LRA. ${ }^{59}$

\footnotetext{
54 Kindi, note 12, p. 12.

55 Kindi, note 12 , p. 14.

56 Uganda Ministry of Lands, Housing and Urban Development, The Uganda National Land Policy, 2013, p. 19, http://landportal.info/sites/default/files/the uganda national land policy- february 2013.pdf. The policy was welcomed by the country office in Uganda of the UN High Commissioner for Human Rights, Report on the Activities of the Office of the United Nations High Commissioner for Human Rights and the Human Rights Situation in Uganda: Nov. 2011 to Sept. 2013, UN High Commissioner for Human Rights, Geneva, February 2013, p. 26, http://www.ohchr.org/Documents/Countries/UG/OHCHRUganda2011 2013.pdf.

57 The Uganda National Land Policy, note 56, p. 31.

58 World Bank, Investment Reforms Key to Uganda 's Growth and Competitiveness, Press release, 14 May, 2013.

59 CSOPNU, Counting the Cost - Twenty years of war in northern Uganda, Report by the Civil Society Organizations for Peace in Northern Uganda, 2006, cited from Mabikke, note 43, p. 5
} 
In the Juba peace agreements between the government and the LRA, negotiated from 2006 to $2008,{ }^{60}$ the issue of land was dealt with briefly in Clause 14 of the Agreement on Comprehensive Solutions. Most of this Clause does not add significantly to what is already provided for in the constitution. However, in Clause 14.4, it is agreed that "no customary or communal land in northern and north eastern Uganda shall be sold or purchased without the express consent of the concerned community", which is echoed in the land policy. ${ }^{61}$ The provision may be intended to deal with the situation where men have sold land without the consent of the clan, where corrupt clan leaders have sold large swathes of land to "investors" or where the government has sold off "public" land - all of this facilitated by the conflict. At any rate, the legal status of this agreement is doubtful, and it has not been implemented as such.

To sum up, the substantive regulation of customary land in Northern Uganda is sophisticated and ensures access to land for all concerned, to a larger degree than most or all "modern", formal land regimes. Nevertheless, the customary system privileges men as heads of house-holds and as the custodians of the traditional institutions, which national land law and official policy seeks to rectify. Land governance, in particular at the local level, is weak and confusing. ${ }^{62}$ A number of different instances can be involved - local courts (land tribunals), district land board and land committees and the customary institutions; ${ }^{63}$ many of these institutions are not operational, others are weak or subject to manipulation. In addition there is the pressure from the commodification of land, promoted both by the government and international institutions. In the war-torn Northern parts, problems were greatly exacerbated by the armed conflict with the LRA, and there are disputes or even conflicts related to land at all levels.

Flora's title under customary law is, in principle, recognized by Ugandan law, but as applied by the traditional leaders in war-torn Acholiland, it privileged her brother-in-law, who could also take advantage of the formal system and register freehold over the plot that had been used by Flora and William. The user right given to her by the elders was not acknowledged by the District Land Board.

\footnotetext{
${ }^{60}$ While the various agreements of the Juba package were signed by representatives of the two parties, the framework agreement was never signed. Parts of it have nevertheless been implemented. The war in Uganda de facto ended in 2007, when the LRA moved into the Democratic Republic of the Congo, where it has been roaming ever since (in addition to frequent encampment in and incursions into the Central African Republic and South Sudan).

${ }^{61}$ This appears to go beyond what is provided in existing law, which allows conversion of customary into freehold without conditions (sec 14), but well in line with the 2013 land policy.

${ }^{62}$ Mabikke, note 43, p. 24.

63 See footnotes 48 and 49.
} 
While the recent land policy could have strengthened her position, it has yet to be implemented. No transitional measures agreed in the peace agreements (like reparation) have been put in effect to help her.

\section{International law and land}

So, the regulation/management of land in Northern Uganda - like in many other places in Africa and other parts of the Third World - is a complex mixture of modern law and customary law. What role does international law play? Could it improve Flora's position?

\section{Sovereignty and the right to development}

Sovereignty empowers certain groups of people, namely governments.

(Sovereignty can be underpinned and in some cases even produced by the right to self-determination of peoples, provided that sovereignty expresses the will of the people. ${ }^{64}$ ) Sovereign states are free to do what they please, as long as there is no contrary regulation under international law. They are free to develop policies and request assistance to implement those policies. In addition, development policies can, possibly, be rationalized under the amorphous and controversial right to development, which is both an individual and a collective human right but difficult to fully operationalize. ${ }^{65}$

Development policies, like all policies, have to be in conformity with other international law obligations (like human rights; see below). While it is self-evident that the recipient states are always legally accountable for their domestic policies, the situation regarding donors and lenders is much less clear.

\footnotetext{
${ }^{64}$ Similarly, access to national natural resources can be justified by sovereignty and by the right of peoples to their natural resources. See UNGA Resolution 1803 (XVII) Permanent Sovereignty over Natural Resources (1962), and Common Article 1(2) of the 1966 UN Covenants.

65 See Declaration on the Right to Development, UN General Assembly Resolution 41/128, 1986. See also Marks, Stephen, The Human Right to Development: Between Rhetoric and Reality, Harvard Human Rights Journal, vol 17, 2004, p. 137-168. Law and development scholars have held law to be an instrument for development, generally meaning increase in per capital output. Under this view, the regulation of land - for instance through land reform - will serve an instrumental, economic purpose. See Ginsburg, Tom, Does Law Matter for Economic Development? Evidence From East Asia, Law \& Society Review, vol. 34, 2000, p. 829-856. The right to development has hardly been an effective tool in development, and has been replaced by the rights-based approach to development, which focuses on empowering the rights-holders (individuals) to claim their rights and to enable the responsible states to fulfil these rights. See OHCHR, Frequently Asked Questions on a Human Rights-Based Approach to Development Cooperation, 2006, http://www.ohchr.org/Documents/Publications/FAQen.pdf. For a critique of the concept of development, see Rajagopal, Balakrishnan, Counter-hegemonic International Law: rethinking human rights and development as a Third World strategy, Third World Quarterly, vol 27, 2006, p. 775-580 and works cited therein.
} 
At least in theory, a donor country could be responsible under customary international law, as codified in the Draft Articles on State Responsibility, for acts which the donor state has directed (Article 17) or assisted (Article 16), but as far as I am aware, there are no examples of such claims. The Paris Declaration on aid effectiveness has a few provisions on accountability for donors, which are not very far-reaching. ${ }^{66}$ Hence, if Flora's condition has been caused by a development policy (favouring investments), all parties are responsible for their actions, but it is hard to pin legal accountability to third states.

\section{International investment law}

This brings us over to international investment law, which applies to foreign investments, including in land. Investors can, in principle, invoke the right to property (see also below), ${ }^{67}$ but they are most effectively protected by specific customary international law principles on expropriation, and by an increasing web of multilateral and bilateral investment treaties (BITs; Uganda has signed 15 $\mathrm{BITs}^{68}$ ). These treaties generally give a right to full compensation in cases of direct or indirect expropriation, and they also provide for "fair and equitable treatment" of the investor.

In addition to the provisions of the BITs, international investment contracts between investors and host states often include stabilization clauses. ${ }^{69}$

Stabilization means that a government cannot change regulations that would have a negative economic impact on the investment, without risking liability for compensation. Perhaps most importantly, it is a standard feature of BITs that investors an bring claims to an international tribunal, without first having exhausted local remedies, and that any arbitral award is enforceable in all states

\footnotetext{
66 See The Paris Declaration on Aid Effectiveness, OECD, 2005, p. 7, http://www.oecd.org/dac/effectiveness/34428351.pdf.

${ }^{69}$ Černič, Jernej Letnar, Corporate Human Rights Obligations under Stabilization Clauses, German Law Journal, vol 11, 2006, p. 210-229, at p. 213. Howse explains the thinking behind these clauses. ''Obsolescing bargain' theory holds that, over time, the bargaining power of the government increases relative to that of the investor. This is because of the hostage effect: having substantial sunk costs, the investor cannot easily walk away from the project." Howse, Robert, Freezing government policy: Stabilization clauses in investment contracts, Investment Treaty News, 4 April 2011, p. 2, http://www.iisd.org/itn/2011/04/04/freezing-government-policy-stabilization-clauses-in-investment-contracts-2/. http://www.mercycorps.org.uk/sites/default/files/mercy corps acholilandconflictmarketassessment aug_2011.pdf. The government of Uganda has signed such concession agreements with oil companies, containing standard stabilization clauses. See Minio-Paluello, Mika, Cursed contracts: Uganda's oil agreements place profit before people, Platform, 2010, p. 27, http://platformlondon.org/wp-content/uploads/2012/01/Contracts-Curse-Uganda-Platform-CSCO.pdf
} 
which are parties to the New York Convention on the Recognition and Enforcement of Foreign Arbitral Awards, which has 149 parties. ${ }^{70}$ In principle, states (but not individuals) can file complaints against investors, but this rarely happens, since investment contracts contain few obligations for investors. ${ }^{71}$ Hence, for a person like Flora, there are no international remedies available if her rights have been violated directly or indirectly by an international investor.

\section{Human rights}

Human rights are drafted with the individual in mind, and in particular the vulnerable ones. Since Flora has been deprived of land, property rights seem to be relevant. The international protection of private property is not universal. It is included in the Universal Declaration of Human Rights, and in three regional human rights conventions, including the African Convention on Human and Peoples' Rights, but not in the International Covenant on Civil and Political Rights or any other global treaty. The Universal Declaration provides in Article 17 that "[e]veryone has the right to own property alone as well as in association with others" and that "[n]o one shall be arbitrarily deprived of his property". ${ }^{72}$ Article 14 of the African Charter on Human and Peoples Rights declares that "[t]he right to property shall be guaranteed. It may only be encroached upon in the interest of public need or in the general interest of the community and in accordance with the provisions of appropriate laws." This protection is quite weak, without any guarantee for compensation in case of expropriation. Article 21(2) provides that "[i]n case of spoliation the dispossessed people shall have the right to the lawful recovery of its property as well as to an adequate compensation," but it appears to be geared to collective rights of peoples rather than to individuals. ${ }^{73}$

The right to property covers not only ownership of land but also other claims, at least in the jurisprudence of the European Court of Human Rights, which has found breaches in cases of forcible eviction of urban squatters and forest dwellers,

\footnotetext{
${ }^{70}$ For disputes under the ICSID procedure, enforcement is simplified. See Convention on the Settlement of Investment Disputes between States and Nationals of Other States, Article 54.

${ }^{71}$ Gehne, Katja, Responsible Investment through International Investment Law : Addressing Rights Asymmetries through Law Interpretation and Remedies, policy brief, International Land Coalition, Mach 2012, p. 2.

72 While the right not to be arbitrarily deprived of property is generally held to serve commutative rather than distributive justice - it is in essence about compensation when the government takes property - the "right to own" may, literally, be interpreted to suggest a duty on the part of the government to ensure that the individual has something to own. The contrast to Article 1 of Protocol 1 to the European Convention on Human Rights is stark: "Every natural or legal person is entitled to the peaceful enjoyment of his possessions." This right is clearly restricted to goods already under the possession of the person. A right to own can be deduced from some economic, social and cultural rights, as will be discussed below. 73 See Vinuales, Jorge E., Global Governance, vol. 17, 2011, p. 197.
} 
administrative difficulties to register land, denial of unregistered grazing or water rights, and the relocation of villages. ${ }^{74}$ As will be explained below, this has been developed in African and Inter-American jurisprudence with regard to indigenous peoples. Hence, it is clear that unregistered traditional user and other property rights of villagers in northern Uganda are covered by the right to property.

Rights of indigenous peoples are often relevant for land rights. ${ }^{75}$ In addition to the economic value, land also has symbolic values. Article 26(1) of the UN Declaration on the Rights of Indigenous Peoples provides that "[i]ndigenous peoples have the right to the lands, territories and resources which they have traditionally owned, occupied or otherwise used or acquired." ${ }^{76}$ Further, under Article 8 (2) (b), states should prohibit "any action which has the aim or effect of dispossessing [indigenous peoples] of their lands, territories or resources", as well as, under Article 10, any removal of indigenous peoples from their lands or territories without their free, prior and informed consent or without just and fair compensation. ${ }^{77}$ No monitoring mechanism is connected to the declaration, although it may be brought up in the Council for Human Rights, including through the reports of the Special Rapporteur on the Right of Indigenous Peoples. Indigenous rights are also protected in ILO Convention No 169, again with a rather weak monitoring system. As mentioned, property rights of indigenous peoples have also been recognized in the case law of regional human rights conventions, both by the Inter-American Court of Human Rights and by the African Commission on Human and Peoples Rights. These bodies consider that the effects of traditional possession of land are equivalent to those of conventional

\footnotetext{
${ }^{74}$ Icelandic Human Rights Centre, The Right to Property, no date, http://www.humanrights.is/the-human-rights-project/humanrightscasesandmaterials/humanrightsconceptsi deasandfora/substantivehumanrights/therighttoproperty/.

75 The right of all peoples to freely dispose of their natural wealth and resources in common Article 1 of the two 1966 UN Covenants on human rights is also relevant for indigenous peoples. This right, which is also covered by Article 21 of the African Charter, has been successfully invoked in two cases before the African Commission: SERAC and CESR v Nigeria and CEMIRIDE and Minority Rights International Kenya v Kenya. In both reports, the Commission also found breaches of Article 14 on the right to property. In the Kenya case, the Commission developed the concept of indigenous people, which was not dealt with directly in the Nigerian case. 155/96 : Social and Economic Rights Action Center (SERAC) and Center for Economic and Social Rights (CESR) / Nigeria Decision on merits, 27 October 2001, para 52 http://www.achpr.org/communications/decision/155.96/; 276/2003 - Centre for Minority Rights Development (Kenya) and Minority Rights Group International on behalf of Endorois Welfare Council v Kenya, Decision on merits, 25 November 2009, http://www.achpr.org/communications/decision/276.03/.

${ }^{76}$ UN General Assembly A/RES/61/295. United Nations Declaration on the Rights of Indigenous Peoples. See also Article 8(2), 10, 25-30 and 32, which together form a quite ambitious regime.

77 See also De Schutter 2010, note 39, p. 7. In addition, the declaration recognizes that indigenous peoples have economic, social and cultural rights as well as the right to development (Article 23).
} 
property title. ${ }^{78}$ This includes also rights in communal property, and rights to unregistered land. ${ }^{79}$

All of this relates to existing rights to particular pieces of land. As noted by De Schutter, land rights are closely related to the right to adequate food, which is recognized under Article 25 of the Universal Declaration of Human Rights 3 and Article 11 of the International Covenant on Economic, Social and Cultural Rights. ${ }^{80}$ The right to food is established as a notion in legal discourse, but it is still controversial if it could imply a right to access to land. According the General Comment 12 of the Committee on Economic, Social and Cultural Rights, the right to food means that every person should have "physical and economic access at all times to adequate food or means for its procurement". ${ }^{81}$ This means the following:

[T] he obligation to respect existing access to adequate food requires States parties not to take any measures that result in preventing such access. The obligation to protect requires measures by the State to ensure that enterprises or individuals do not deprive individuals of their access to adequate food. ${ }^{82}$

Under the duty to fulfil, the state also has a duty to facilitate access to food or, as a last resort, to provide food. ${ }^{83}$ Hence, the right to food complements property rights against encroachments by both public and private actors. For those that do not have adequate access to land or other resources to begin with, the state may need to redistribute land. ${ }^{84}$ This may actually turn into a right to own property,

\footnotetext{
78 De Schutter 2010, note 39, p. 8.

79 Icelandic Human Rights Centre, "The Right to Property", no date, http://www.humanrights.is/the-human-rights-project/humanrightscasesandmaterials/humanrightsconceptsi deasandfora/substantivehumanrights/therighttoproperty/. Among cases often cited one finds two cases from the African Commission for Human and People's Rights (see note 74), the following judgments in in the Inter-American Court of Human Rights: Mayagna (Sumo) Awas Tingni Community v. Nicaragua (judgement of 31 August 2001), para. 148; Sawhoyamaxa Indigenous Community v. Paraguay (judgement of 29 March 2006), para. 120, as well as judgments in domestic courts in Canada and South Africa.

${ }^{80}$ De Schutter 2010, note 39, p. 3-4. This fact led the former Special Rapporteur on the right to adequate housing to conclude that the Human Rights Council should "ensure the recognition in international human rights law of land as a human right".

${ }^{81}$ Committee on Economic, Social and Cultural Rights, General Comment 12: The right to adequate food (art. 11), E/C.12/1999/5, 1999, p. 3.

82 Committee on Economic, Social and Cultural Rights, General Comment 12: The right to adequate food (art. 11), E/C.12/1999/5, 1999, p. 5.

83 Ibid.

${ }^{84}$ De Schutter 2010, note 39, p. 4. This fact led the former Special Rapporteur on the right to adequate housing to conclude that the Human Rights Council should "ensure the recognition in international human rights law of land as a human right". "General Comment No. 4 on the Right to Adequate Housing" (1991), adopted by the UN Committee on Economic, Social and Cultural Rights" is also relevant to land rights.
} 
rather than a right to one's own property. In such cases, the potential land right of a person may materialize into a concrete land right that may conflict with a previous right of another (presumably much more wealthy) owner of the same piece of land.

Access to and ownership of land is often limited for certain categories, be it women or disadvantaged ethnic groups. International human rights law has a number of provisions which prohibit discrimination, for example the general prohibition of discrimination in Article 26 of the International Covenant on Civil and Political Rights, as well as Article 5 (d) (v) of the Convention on the Elimination of All Forms of Racial Discrimination. ${ }^{85}$ Article 2(2) of the UN International Covenant on Economic, Social and Cultural Rights prohibits discrimination in the enjoyment of the rights set out in that covenant. ${ }^{86}$ Even more specifically, Article 14, paragraph 2 (g), of the Convention on the Elimination of All Forms of Discrimination against Women guarantees the right of women to "equal treatment in land and agrarian reform as well as in land resettlement schemes."

A person who has suffered a violation of human rights has the right to challenge that in a court. The right to remedy is guaranteed in all human rights conventions and is developed in the UN Basic Principles and Guidelines on the Right to a Remedy and Reparations for Victims of Gross Violations of International Human Rights Law and Serious Violations of International Humanitarian Law. ${ }^{87}$

Hence, there are a number of human rights obligations of states that should guarantee both security in and access to property. However, it is important to note that while human rights respond to commutative justice (protection of existing property or compensation) and a distribution of minimum resources, human rights law has little or nothing to say about distributive justice above that minimum level. Rights are not about substantive equality. Hence, once the human rights to food, housing etc, have been satisfied, schemes of, say, land retribution or land equalization are beyond the remit of human rights. ${ }^{88}$

\footnotetext{
${ }^{85}$ It provides that states shall "guarantee the right of everyone, without distinction as to race, colour, or national or ethnic origin, to equality before the law" of "[t]he right to own property alone as well as in association with others".

${ }^{86}$ Article 2(1) of the International Covenant on Civil and Political Rights has the same effect as regards the rights set out in that convention.

87 UN Doc GA Res 60/147 of 16 December, 2005, http://www.ohchr.org/EN/ProfessionalInterest/Pages/RemedyAndReparation.aspx.

${ }_{88}$ According to Atuahene, the difference between these two concepts is the following: "The starting point for land equalization is that everyone is entitled only to his or her fair share of land. Under land redistribution, the state assumes current owners are entitled to their current land holdings, so to acquire their land, the state
} 
More importantly, there are limitations both in the reach of these rights and in their enforcement. First of all, it is difficult to hold some of the most important actors to account for human rights violations. Human rights norms are most likely not binding on non-state actors, at least not as far as hard, international law obligations are concerned. As far as states other than the territorial state are concerned, the better view is that state obligations for civil rights obligations apply also extraterritorially. ${ }^{89}$ It is less clear to what extent the obligation of states to protect property rights extend to acts in foreign countries by corporations incorporated in the obligated state. It is also controversial whether extraterritoriality applies also to obligations regarding economic, social and cultural rights. However, some sources indicate that that is the case, and that it is true both for the obligation to respect and the obligation to protect against abuses by companies incorporated in the country concerned. ${ }^{90}$

Secondly, enforcement is weak. The African Convention has a monitoring mechanism in the form of a commission and a court. Neither the commission nor the court has any enforcement measure at its direct disposal, but the African Union can impose sanctions for failure to comply with decisions by any of its organs. ${ }^{91}$ Compliance with The Universal Declaration on Human Rights falls under the mandate of the UN Human Rights Council, but it is extremely unlikely that property rights as such will be dealt with by that body. ${ }^{92}$ The treaty bodies of

must wait for current owners to willingly sell their land, or the state can invoke eminent domain and pay the current owners just compensation." Atuahene, Bernadette, Property and Transitional Justice, UCLA L. Rev. Disc., vol 58, 2010, p. 65-93, at p. 87. Of course, human rights may be relevant in such schemes to the extent that the right to property limits the possibilities to institute a land equalization scheme.

A fair distribution of land could be based on efficiency in order to secure food for everyone, at least if it is correct that there is an "inverse relationship between farm size and productivity". See De Schutter 2010, note $39, \mathrm{p}, 14$.

${ }^{89}$ See, for instance, Human Rights Committee, General Comment 31, Nature of the General Legal Obligation on States Parties to the Covenant, U.N. Doc. CCPR/C/21/Rev.1/Add.13 (2004), paragraphs 3, 6 \& 10.

${ }^{90}$ De Schutter, Olivier, "Interim Report of the Special Rapporteur on the Right to Food" United Nations Human Rights Council, A /68/288, 2013, p. 9 [De Schutter 2013]; 'Maastricht Principles on Extraterritorial Obligations of States in the area of Economic, Social and Cultural Rights', 2011;

http://www.maastrichtuniversity.nl/web/institutes/maastrichtcentreforhumanrights/maastrichtetoprinciples .htm, 2014, paras 21 and 24-26; Guiding Principles on Extreme Poverty and Human Rights, endorsed by the Human Rights Council on 27 September 2012 (A/HRC/21/39, para. 61, 92); UN Committee on Economic, Social and Cultural Rights (CESCR), General Comment No. 12: The Right to Adequate Food (Art. 11 of the Covenant), 12 May 1999, UN Doc E/C.12/1999/5, para 36. See also Skogly, Sigrun, Right to Adequate Food: National Implementation and Extraterritorial Obligation, Max Planck Yearbook of United Nations Law, 2007, vol. $11,339$.

${ }^{91}$ See Article 23 of the Constitutive Act of the African Union. See further Wachira G, "African Court on Human and Peoples' Rights: Ten Years on and Still No Justice" (2008)

http://www.refworld.org/pdfid/48e4763c2.pdf.

${ }_{92}$ Property rights may, however, be related to other issues being discussed in that body, such as the rights of 
the UN human rights conventions can also hear cases - if they have jurisdiction but their findings are not binding.

Flora's right to the land that she is tilling is covered by the right to property and indirectly by the right to food. She should be protected against discrimination and she has a right to a remedy. The main problem is the lack of effective enforcement.

\section{Transitional justice}

In post-conflict situations, like the one in Northern Uganda, there is often an enhanced attention by the international community, due to the urgency of stabilizing such situations. Therefore, a number of special procedures for post-conflict situations have been developed under the label of transitional justice (TJ). ${ }^{93}$ Criminal prosecutions are being complemented by for instance truth and reconciliation procedures and reparations (including restitution and compensation). ${ }^{94}$

Restitution and compensation can be viewed from an instrumental perspective to address humanitarian problems or political grievances, but they can also be conceptualised in terms of commutative justice, to restore the position of the victim or to correct structural injustices (distributive justice). ${ }^{95}$

While the usual human rights rules apply also in a post-conflict situation, a self-standing right to restitution is beginning to get recognized. ${ }^{96}$ Restoration is addressed through the established - but underutilized - TJ mechanism reparation, which includes restitution, compensation (if restitution is not

refugees and of internally displaced persons or women's rights.

93 The concept has a long history and first grew out of situations of transition from dictatorship to democracy, like much of Latin America in the 1980s. This is not the place to trace the history and development of this field; suffice it to say that TJ is now a professional and scholarly field populated by people from international criminal law, human rights law, conflict resolution, anthropology and other fields, and lately the debate has also been more attentive to development. See, for example, Bell, Christine, Transitional Justice, Interdisciplinarity and the State of the 'Field' or 'Non-Field', International Journal of Transitional Justice, vol 3, 2008, p. 5; Teitel Ruti, Editorial Note-Transitional Justice Globalized, International Journal of Transitional Justice, vol 2, 2008, p. 1.

${ }^{94}$ It is still the case, though, that both the literature and the international "tool-box" is considerably less developed for land issues including reparations than for criminal justice or truth and reconciliation.

95 Needs and wishes relating to land, including access to food, return and restitution, are often the top priorities of victims of war. The respondents in one survey in Northern Uganda listed food as their top priority. Pham, Phuong N., Vinck, P., Wierda, M., Stover, E., Forgotten Voices: A Population-Based Survey on Attitudes About Peace and Justice in Northern Uganda, The International Center for Transitional Justice and the Human Rights Center, University of California, Berkeley, 2005, p. 23 \& 25.

${ }_{96}$ Hurwitz et al, note 10, p. 3. See the so-called Pinheiro Principles, UN Sub-Commission on the Promotion and Protection of Human Rights, Principles on Housing and Property Restitution for Refugees and Displaced Persons, 28 June 2005, E/CN.4/Sub.2/2005/17, adopted by the Sub-Commission on 11 August, 2005. The second principle states that [t]he right to restitution exists as a distinct right". 
available ${ }^{97}$ ), rehabilitation, satisfaction and guarantees of non-repetition. ${ }^{98}$ However, in order for restitution to work well, it is necessary that the rightful owners of land can be identified. In regions dominated by customary tenure, rights are usually not documented, and if they are, women's rights are rarely registered, ${ }^{99}$ and the same is the case for communal ownership. ${ }^{100}$ Further, restitution may reintroduce old power-structures, very often gendered.

Conventional reparations programs aim at return to status quo, and therefore do not attend to those who did not own anything before the conflict. ${ }^{101}$ Several authors have argued that transitional justice should cover also social injustice, and go beyond restitution to the status quo ante, which might have been the very cause of the conflict. ${ }^{102}$

To summarise: Flora could have benefitted from a right to restitution, but the traditional institutions did not recognize her right to the plot, and no right to restitution has been enforced against them.

\section{The aggregate, irrational and contested results}

\section{How international law works}

As recounted in section 2, there are many ways to regulate the use of land based on different conceptions of justice. In sections 3 and 4 , we have seen that a number of interests related to land are protected by different international and national legal regimes. These regimes prioritize different values and provide norms which may yield contradictory results. This hodge-podge of norms could be analysed from different perspectives, for instance legal pluralism, ${ }^{103}$ but my

\footnotetext{
97 Between compensation and restitution, the latter should be the preferred remedy. Pinheiro Principles, Principles on Housing and Property Restitution for Refugees and Displaced Persons, 28 June 2005, E/CN.4/Sub.2/2005/17, adopted by the UN Sub-Commission on the Promotion and Protection of Human Rights on 11 August, 2005, para 2.2. This priority is implied also in the ILC Draft Articles on State Responsibility, Article 36(1).

98 UN Basic Principles and Guidelines on the Right to a Remedy and Reparations for Victims of Gross Violations of International Human Rights Law and Serious Violations of International Humanitarian Law, 16 December, 2005, UN Doc GA Res 60/147, para 18, http://www.ohchr.org/EN/ProfessionalInterest/Pages/RemedyAndReparation.aspx.

${ }^{99}$ Kindi, note 12, p. 9.

100 Cf Wily, note 28, p. 37.

101 Atuahene, note 87, p. 78.

102 Mani, note 117, p. 28; Wily, note 28, p. 28. See also See also Atuahene, note 87, p. 65-93 on the concept of restoration. See also Laplante, Lisa J, Transitional Justice and Peace Building: Diagnosing and Addressing the Socioeconomic Roots of Violence through a Human Rights Framework, International Journal of Transitional Justice, vol 2, 2008, p. 331-355, at p. 351.

${ }^{103}$ Legal pluralism can essentially have two meanings. In the weak sense, it means that there are various sources of norms - such as international legislation, domestic legislation, trade customs, customary norms
} 
business in this article is to say something about international law.

In a Hobbesian state of nature, in which communities live without international regulation, Flora's environment would be much different - not necessarily more just, but simpler and probably more coherent. Order would be upheld through local norms and perhaps through ad hoc arrangements with neighbouring communities. Business between foreigners and Acholi would depend on the relations between the visitors and the local powers.

Around the turn of the last century, international law entered Flora's tracts along with foreign colonialists. Power over Uganda - until then a group of smaller kingdoms and tribal areas - was vested in governments in Kampala, first the British governor and then the independent government. Such people may be more enlightened, democratic and altruistic than local leaders, or they may be ignorant, despotic and greedy.

After this basic rearrangement of governmental power, international law and international actors have intervened in a number of ways, as "donors" and in other roles ${ }^{104}$-- often out of benevolence, but surely not exclusively so.

First of all, donors and international financial institutions (IFIs) generally champion domestic policies that support development as "modernization". Such measures may constitute political or legal conditions for credits and other forms of financial assistance ("conditionalities"105), like the structural adjustment programs developed under the "Washington consensus", often to the detriment of social services for local people. ${ }^{106}$

etc, which all derive their binding nature from a nexus to the state. In the strong sense, legal pluralism means that there may be more than one legal system in a given territory, with no necessary state nexus, since the basis of a legal system is a social field, rather than a state. See Griffiths, J., What Is Legal Pluralism?, Journal of Legal Pluralism and Unofficial Law, vol 24, 1986, p. 1; von Benda-Beckmann, F., Who's Afraid of Legal Pluralism, J. Legal Pluralism \& Unofficial L., vol 47,2002, p. 37 at p. 63; Bell, Christine, Transitional Justice, Interdisciplinarity and the State of the "Field" or "Non-Field," INTERNATIONAL JOURNAL Of Transitional JuSTICE vol 3, 2008, p. 5-27 at p. 20.

${ }^{104} \mathrm{I}$ am here using the term that was used most commonly in Uganda, not least by Ugandans themselves. Many "donors" prefer the term "development partner", which is the term used in OECD-DAC and many other international organs.

105 Tsai, Mary C., Globalization and Conditionality: Two sides of the sovereignty coin. Law \& Pol'y Int'l Bus., vol. 31, 1999, p. 1317. Such conditionalities are not forced upon the lender in a strict sense, since the government of the developing state is, in principle, free to accept or reject the conditions. However, in reality, it has very often been an offer that one cannot refuse, since the borrowing state has been in need of the credits etc. Uganda has certainly been affected by these policies. See, for instance, Donors set conditions for aid to Uganda, Reuters, 16 October 2009, www.reuters.com/article/2009/10/16/ozatp-uganda-donors-idAFJOE59F0BU20091016.

106 While it is certainly true that many of the economies of recipient states where mismanaged, the cures imposed where widely criticized. For a more or less random example, see the following article, which 
This can include support to registration and titling of land, motivated by foreign economic doctrines and enabled through international agreements. As has been explained above, such often useful activities may replace more sophisticated arrangements, like latent user rights of women and underlying management rights of the clan or other local communities. They will benefit some more than others, and may reinforce historical inequalities and further marginalize the poor. ${ }^{107}$ Registration of land will, in general, strengthen commutative justice rights of persons like Flora's brother-in-law at the expense of communal rights, while the titles of others, like Flora, will not be recognized. ${ }^{108}$

States and international institutions may also promote foreign investment, by concluding bilateral investment treaties, by supporting investment-friendly legislative reforms or by promoting and financing concrete investment projects. ${ }^{109}$ "Investments" may or may not be advantageous for macro-economic development, ${ }^{110}$ and may bring job opportunities for local inhabitants. However, they may also disenfranchise some individuals if rights provided to a foreign investor are disputed (a government may have offered "public" land to an investor, while that land is being claimed by a community as customary land).

BITs and in particular stabilisation clauses have a "chilling effect" on a state's willingness to impose new regulations in labour law or environmental law, as well as its willingness to introduce land reforms or to "retroactively" recognize traditional land rights, if that affects current investments. ${ }^{111}$ For instance, if the

includes an assessment of the effects in Uganda: Jauch, Herbert, How The IMF-World Bank and Structural Adjustment Program (SAP) Destroyed Africa, NewsRescue.com, 19 July, 2012,

http://newsrescue.com/how-the-imf-world-bank-and-structural-adjustment-programsap-destroyed-africa/\#a xzz3B77oDBPi.

${ }^{107}$ European Commission. EU Guidelines to support land policy design and reform processes in developing countries, Communication from the Commission to the Council and the European Parliament, COM(2004) 686, 2004 [cit: EU Guidelines], p. 7 and 26; Huggins, note 32, p. 2; Hurwitz et al, note 10, p. 4.

${ }_{108}$ Conversely, donors can also - but less likely -- support the strengthening or reinstatement of customary law institutions, which also may be for good or for bad.

${ }_{109}$ Cf EU Guidelines, note 105, p. 6. For an example, see the very controversial Kalangala Oil Palm Project, supported by international institutions like the International Finance Corporation and the International Fund for Agricultural Development . See i.a. Vegetable Oil Development Project, IDAD,

http://operations.ifad.org/web/ifad/operations/country/project/tags/uganda/1021/project overview; Vidal, John and Provost, Claire, Campaigners claim World Bank helps facilitate land grabs in Africa, The Guardian, 23 April, 2012, http://www.theguardian.com/global-development/2012/apr/23/world-bank-land-grabs-africa. 110 Of course, growth at the national level, thanks to a more efficient use of land, may not necessarily lead to the reduction of poverty, and may increase injustice, under some views. Cf de Gaay Fortman, Bas, Poverty as a Failure of Entitlement: Do Rights-Based Approaches Make Sense?, in Williams, L, International Poverty Law: An Emerging Discourse, Zed Boooks 2006, p. 34, at p. 44-45.

${ }^{111}$ See, for instance, Shemberg, Andrea, Stabilization Clauses and Human Rights, A research project conducted for IFC and the United Nations Special Representative to the Secretary General on Business and Human Rights, 11 March 2008, p. 33-36, 
Government of Uganda were to implement the land policy and introduce "[m]echanisms for appeal and arbitration" in disputes between investors and local inhabitants (like Flora), that could result in decisions unfavourable to the investor. ${ }^{112}$

In conflict situations, donors can provide humanitarian assistance. During the LRA conflict in northern Uganda, such assistance enabled a scheme of "protected villages" (IDP camps), where most inhabitants - including Flora - were forced to live. This enabled the survival of many displaced people but it also created a situation which facilitated land grab and generated many conflicts between the villagers upon their return years later. ${ }^{113}$

In post-conflict situations, international norms and actors are often very influential. However, while land issues are generally taken into account for the right of the return of refugees and internally displaced persons, less attention is given to property rights as such. This is very unfortunate for people like Flora, and it is also quite astonishing from a conflict-prevention perspective (which is the perspective taken by most actors in these situations.) In civil wars, land problems, and not least problems related to "the dubious legal position of customary land interests", may be both a root cause and a consequence of the war, and may be a trigger of the next conflict. ${ }^{114}$ However, even though there is a growing awareness of this problem, and even though land has been discussed in transitional justice foras, ${ }^{115}$ these issues have not been prominent in transitional justice processes or in peace-building in general. ${ }^{116}$

http://www.ifc.org/wps/wcm/connect/9feb5b00488555eab8c4fa6a6515bb18/Stabilization\%2BPaper.pdf?MOD =AJPERES. See also, more generally on international investment law Romson, Åsa, Environmental Policy Space and International Investment Law, Acta Universitatis Stockholmiensis, 2012.

112 Another example: The US assessment on the investment climate in Uganda complains, with regard to so-called mailo land (a form of ownership particular to Uganda), that "[t]he 2009 Land Bill complicated this further by giving occupants and squatters increased rights on mailoland at the expense of owner rights." US Embassy in Kampala, 2011 Investment Climate Statement - Uganda, p. 21,

http://kampala.usembassy.gov/media/pdfs/uganda_2011 investment_climate_statement.pdf. Foreigners cannot own mailoland, but if this had applied to land covered by a stabilization clause, the Government should have been wary of suggesting such increased protection.

113 See Branch, Adam, Displacing Human Rights: War and Intervention in Northern Uganda, Oxford University Press, Oxford, 2011. This humanitarian assistance was necessary for the bare survival of the population. However, it also enabled to Government to pursue this very controversial strategy.

114 Wily, note note 28, p. 36; See also Hurwitz et al, note 10, p. 2; Huggins, note 32, p. 2; Mani, Rama, Balancing Peace with Justice in the Aftermath of Violent Conflict, Development, vol 48, 2005, p. 25-34, at p. 26. See also Kindi, note 12, p. 18; Mabikke, note 43, p. 23. According to Wily, customary land has been "a fundamental element in the grievances driving people to war and emerging out of war as a concrete target of remedy" in all but three of more than 30 conflicts in Africe from 1990. Wily, note note 28, p. 36.

115 See, for instance, note 32.

116 Huggins, note 32, p. 3; Rama, Mani, Balancing Peace with Justice in the Aftermath of Violent Conflict, 
Transitional justice processes could protect commutative rights of war victims in the form of reparations, but when donors and other outside forces intervene in peace and transitional processes, that is generally only to support criminal accountability and/or to strengthen rule of law institutions. Prosecutions of war criminals may be welcomed by the population, but will not help them access land. ${ }^{117}$ To strengthen the rule of law will have positive effect for people in Flora's position, if the relevant substantive norms are helpful and relevant.

The set of international rules that are most promising to Flora and others like her is human rights. Human rights protect commutative justice of all concerned, for instance through property rights, but also social and economic rights. It could be reasonably argued that Flora has been subjected to a number of human rights violations, including illegal deprivation of property, a violation of the right to food and the right to housing as well as a denial of justice. However, human rights obligations are enforced unevenly. As mentioned above, international HR mechanisms are weak, and in those rare instances when third states or international organizations intervene, that is usually only to enforce political and civil rights other than poor people's right to property ${ }^{118}$ and generally only when the violations have reached the level of sever persecution. ${ }^{119}$

\section{Irrationality and fragmentation of international law}

International law empowers national governments to rule over people and territory, without asking a lot of hard questions about how they came into power. ${ }^{120}$ Most rules of international law can de facto - but not always - be set aside by national decisions - good or bad - because national institutions are more effectual than international ones. That is not always the case, though. There are

Development, vol 48, 2005, p. 25-34, at p. 25. Leckie notes that " in no two post-conflict peace operations during the past two decades have consistent policies on these complex HLP concerns been put in place." Leckie, Scott, Possible Components of a Unified Global Policy on Housing, Land, and Property Rights in UN Peace Operations, in Leckie, Scott (ed.), Housing, Land, and Property Rights in Post-Conflict United Nations and Other Peace Operations: A Comparative Survey and Proposal for Reform, Cambridge University Press, 2008, p. 329-356, at p. 337.

117 See note 95.

118 The U.S. (Second) Hickenlooper amendment of 1965 is a famous example of US action to protect the property rights of US investors abroad. See, for instance, Vandevelde, Kenneth J, Reassessing the Hickenlooper Amendment, Va. J. Int'l L., vol 29, 1988-1989, p. 115.

119 For an interesting proposal to criminalize acts of kleptocracy, and thus to put corruption on the same level of seriousness as international crimes, see Eboe-Osuji, Chile, Kleptocracy: A Desired Subject of International Criminal Law That Is in Dire Need of Prosecution by Universal Jurisdiction, in Ankumah, Evelyn A. and Kwakwa, Edward (eds.), African Perspectives on International Criminal Justice, Africa Legal Aid, Accra, 2005, p. 121132.

${ }^{120}$ Lately, however, practice is tilting towards a global policy of de facto non-recognition of overt military coups. 
strong incentives for states (that is, governments) to comply with legal and political obligations vis-à-vis donors and lenders. There are also strong incentives to comply with obligations under investment treaties; not only will breaches deter future investors, they may also result in arbitral judgments, enforceable almost anywhere. This is not unfair in and of itself, because other states as well as investors have a right to expect compliance with obligations. However, such expectations may be illegitimate if the obligations were assumed by a corrupt government. ${ }^{121}$ By contrast, accountability procedures for human rights obligations are weak and the effect of the rules is ephemeral, unless strong external powers decide to enforce compliance (which would hardly happen in a case like Flora's). So, while territorial governments often can avoid implementing their obligations, in particular obligations to their own people, some parties can have some international obligations enforced.

Donors and other "partners" of developing states are rarely if ever held responsible; even though there is - in principle - legal accountability for states that assist other states in illegal acts, it is much more difficult to find legal accountability for giving (and enforcing) bad or controversial advice on economic or land policies or for providing humanitarian assistance than de facto enables a flawed (and catastrophic) politico-military strategy (like the "protected villages"). As mentioned in section 3, there is good legal basis for arguing that human rights obligations apply extraterritorially, including the obligation to protect against abuses committed by private parties. However, as applied, human rights are not being enforced against other states and private parties.

International investment law protects commutative justice rights of investors, including by bypassing domestic law and institutions through international investment arbitration. ${ }^{122}$ Since BITs and investment contracts generally do not contain any obligations for investors relevant to human rights, the host state has little chance of suing an investor, and aggrieved local inhabitants have no standing at all. ${ }^{123}$ Add to that the fact that developing states often have a weak

\footnotetext{
${ }^{121}$ For sure, corruption of a state representative will generally make an agreement voidable (see Article 50 of the Vienna Convention on the Law of Treatiese, which expresses general principles of contract). However, besides the diffulty of proof, that hardly applies when the whole government is corrupted.

122 As noted above, although it is true that this requires an initial political decision to enter into a BIT, thereafter the situation is frozen.

${ }^{123}$ Regarding human rights concerns, cf Reiner, Clara and Schreuer, Christoph, Human Rights and International Investment Arbitration, in Dupuy, Pierre-Marie and Petersmann, Ernst Ulrich, eds, Human Rights in International Investment Law and Arbitration, 2009, p. 89-96. See also Gehne, note 71, p. 1-2; International Law Association, International Law on Foreign Investment, Final Report, 2008, p. 15, file://C:/Users/P\%C3\%A51/Downloads/report rio 2008.pdf. See also Černič, note 68, p. 226.
} 
bargaining position and that they sometimes collude with investors, ${ }^{124}$ and it is clear that a person who claims that she is the subject of a human rights violation committed by an investor - directly and indirectly - has little chance of suing that investor. ${ }^{125}$ Businesses may have signed up to corporate social responsibility standards, ${ }^{126}$ but they are never held legally accountable for such standards under international law (and only rarely under domestic law). ${ }^{127}$ As mentioned, even less responsibility attaches to the home state of the investor, when it promotes and protects the investment.

The end result is that there is no forum where Flora has standing to effectively hold either the government or an investor to account.

I do not claim here that the various measures by different actors (donors, investors, etc) that I have mentioned are always detrimental to the people concerned, and even less that they are malevolent. Nor do I claim that the substantive rules of international law are unfair - although some rules might be. My present claim is much more limited, namely that it appears that some such measures are detrimental, and that there is no generally feasible way of holding the responsible actors accountable. The problem is that the dispute settlement and enforcement architecture only enable some actors to hold some other actors responsible for some acts.

Further, I do not claim that international law should impose justice everywhere and always. International law leaves most choices of justice unregulated, and for good reasons - justice is controversial, and should be deliberated and contested by the community concerned. ${ }^{128}$ However, international law, as supported and

124 The business interests of the investor is often in line with the macroeconomic interest of the government, and sometimes in line with the private interests of corrupt government officials. Heri, Simone et al,

International instruments influencing the rights of people facing investments in agricultural land, International Land Coalition, Rome, 2011, 92.

125 There is a growing number of cases where corporations have been sued in their home states for human rights related torts, but the hurdles for bringing such a suit are very high. See Blumberg, Phillip I., Asserting Human Rights against Multinational Corporations under United States Law: Conceptualand Procedural Problems , The American Journal of Comparative Law, Vol. 50: Supplement: American Law in a Time of Global Interdependence: U. S. National Reports to the 16th International Congress of Comparative Law, 2002, p. 493-529.

126 For a summary of CSR guidelines applicable to investment in land, see the following FAO Report: CFS Open Ended Working Group on principles for responsible agricultural investments which enhance food security and nutrition, Consultancy output 2: Comparative analysis of selected instruments on responsible investment: similarities, differences and gaps, 29 January 2013, http://www.fao.org/fileadmin/templates/cfs/Docs1314/rai/CFS RAI Comp Anal Sel_Instruments EN.pdf. 127 The most realistic danger is the court of public opinion, or consumer power, but that is effective only when there are NGOs or media that are interested in the events, and mainly if the company concerned is consumer oriented.

${ }^{128}$ What is "the community concerned" is, of course, a complicated issue as such, with different answers in 
enforced by the powers that be, does intervene in accordance with some types of justice to protect some interests of some parties, at the potential expense of others.

Hence, what makes international law irrational is that states have, in deeds rather than in words, prioritized some regimes over others. The aggregate effect is a privileging of states over people, strong states over weak states, and international investors over people.

The opposite of integrity is fragmentation. In its famed report on the fragmentation of international law, the study group of the International Law Commission concluded:

(28) Settlement of disputes within and across regimes. ... When the conflict concerns provisions within a single regime ... then its resolution may be appropriate in the regime-specific mechanism. However, when the conflict concerns provisions in treaties that are not part of the same regime, special attention should be given to the independence of the means of settlement chosen. $^{129}$

Read these cautiously worded recommendations carefully - "special attention should be given to the independence of the means of settlement chosen". The problems associated with fragmentation apply to cases where one dispute settlement or monitoring body is tasked with situations that imply more than one regime, in particular when strong regimes do not allow weaker regimes to be heard and balanced and the dispute settlement body makes no or little effort to remedy this imbalance. Some scholars would call this "regime bias", i.a. in relation to investment disputes. ${ }^{130}$ For instance, even if it is - in principle, though not yet in practice - possible for states to submit a dispute concerning human rights abuses by an investor to arbitration, that is very rare, and even if it did happen, there is no guarantee that the arbitrators would look much beyond the treaty itself. ${ }^{131}$

It could have been for a Ronald Dworkin's Hercules lawapplier to balance these

\footnotetext{
different situations.

${ }^{129}$ International Law Commission, Conclusions of the work of the Study Group on the Fragmentation of International Law: Difficulties arising from the Diversification and Expansion of International Law, Submitted in its report on the work of its fifty-eighth session, UNGA A/61/10 (2006) p. 417-418.

${ }^{130}$ Van Harten, Gus, TWAIL and the Dabhol Arbitration, Trade, Law and Development, vol III, 2011, p. 131, on regime bias as applied to the famous Dabhol case. See also Hippolyte, Antonius R., Aspiring For a Constructive TWAIL Approach towards the International Investment Regime, working paper, 2014, p. 2. For an opposite view, See Hobér, Kaj, Selected Writings on Investment Treaty Arbitration, Studentlitteratur, 2013, p. 533-540. http://www.academia.edu/Documents/in/Third World Approaches to International Law TWAIL ;

131 See Gehne, note 71, p. 1.
} 
various interests and principles against one another. ${ }^{132}$ However, there is no Hercules in international law. Or, rather, Hercules is not allowed to do his job. Instead, conflicts are resolved under different regimes created for different purposes and with different dispute settlement mechanisms open to different parties. Who - that is, which interest - wins depends not on what is the more important or worthy interest from a general point of view (if there is one), ${ }^{133}$ but on whose interest has been given the strongest procedural (or political) backing.

Alternatively, the balancing between the various interests could have been done by a world legislator, who would not only consider potential conflicts between the rules but also introduce appropriate dispute settlement and monitoring mechanisms for all obligations. However, there is no such thing, just ten scores of governments who negotiate agreements in different formats under different circumstances. In fact, international investment law is generally created in a bilateral format, far away from the limelight of multilateral negotiations, in which inequality of bargaining power is common. ${ }^{134}$

There is no Hercules lawapplier in international law, nor is there an enlightened philosopher-lawmaker. And perhaps we shouldn't ask for one - how could they avoid bias? International law is the result of various forces (and serendipities), and can be changed or used in many ways, including by people on the ground. The structural problems that I have recounted can be tempered -- universally or locally -- through political and legal contestation.

\section{Contestation and changes}

First: Civil society, including social movements, local and international (sometimes organized as NGOs) can play a role in changing, or adjusting, the rules. ${ }^{135}$ The EU has been criticized "for ignoring its obligations under

\footnotetext{
132 On Hercules, see Dworkin, note 1.

${ }^{133}$ In principle, the ICJ can be seized with investment law cases, which has happened on a few occassions, most famously in Barcelona Traction, Light and Power Company, Limited, Judgment, ICJ Reports, 1970, p. 3, and most recently in Ahmadou Sadio Diallo (Republic of Guinea v Democratic Republic of the Congo), (Merits: Judgment), ICJ Report, 210,, p. 639, which is a case with a human rights dimension, though not directly relevant to the issues discussed in this essay. However, this presupposes that the complaint is being framed as a case between two states, and that the Court has jurisdiction over it.

${ }^{134}$ For instance, the US Model BIT is basically a "take it or leave it" proposition. Hippolyte, Antonius R., Aspiring For a Constructive TWAIL Approach towards the International Investment Regime, working paper, 2014, p. 14, http://www.academia.edu/Documents/in/Third World_Approaches to International Law TWAIL; After the Lisbon Treaty (see note 138), the EU has competence to negotiate investment agreements on behalf of all of the member states. However, these agreements will in essence also be bilateral, with the EU as a gigantic party on one side. Whether the EU will take a more balanced approach remains to be seen. ${ }^{135}$ See generally, Rajagopal,, Balakrishnan, International Law from Below: Development, Social Movements and Third World Resistance, Cambridge University Press, 2003.
} 
international human rights law" regarding land acquisitions, ${ }^{136}$ and there have been many calls for the EU to include human rights concerns in its negotiations with third states on trade and investment agreements. ${ }^{137}$ The work within the Commission to formulate an investment policy, which is called for by the Treaty of Lisbon $^{138}$ and the ongoing negotiations with the US about a treaty on Transatlantic Trade and Investment Partnership (TTIP), has been embroiled in controversy and has prompted a "public consultation". The Commission now states that EU agreements will "reaffirm the right of the Parties to regulate to pursue legitimate public policy objectives" and that "when the state is protecting the public interest in a non-discriminatory way, the right of the state to regulate should prevail over the economic impact of those measures on the investor." ${ }^{139}$ It is too early to say what the outcome of this process will be, but it is clear that protests from international NGOs and local social movements have had an effect. This debate is a sign of the increased attention of critics of globalisation on investment treaties and arbitration. ${ }^{140}$

Second: Civil society can also take political and legal action at the local level. As already indicated, Flora Alanyo is a fictional figure, created by me for illustrative purposes. Her story is, in fact, a compound of two different stories - those of an alleged land grab by a domestic investor enabled by the war in Northern Uganda, and those of an alleged land grab by a multinational corporation in Western Uganda.

In the Amuru district in Acholiland, the government is supporting plans by the

\footnotetext{
136 Verhoog Suzanne, The Politics of Land Deals - A Comparative Analysis of Global Land Policies on Large-Scale Land Acquisition, conference paper, 2013, p. 18, http://www.landdivided2013.org.za/sites/default/files/The\%20Politics\%20of\%20Land\%20Deals, $\% 20 \mathrm{March} \%$ 2020,\%202013\%20Suzanne\%20Verhoog.pdf

137 For an example, see a letter from FIDH to the European Commission, Open letter: EU negotiations with Vietnam, DG Trade called on to carry out HRIA, 4 July 2014,

http://www.fidh.org/en/european-union/15826-open-letter-eu-negotiations-with-vietnam-dg-trade-called-on -to-carry-out.

138 Since the entry into force of the Treaty of Lisbon in 2009, the exclusive competence of the EU over its Common Commercial Policy now covers also investment treaties, according to Article 207(1) of the Treaty on the Functioning of the European Union See, for instance, Cotula, Lorenzo, Europe's controversial TTIP treaty: The good, the bad and the unnecessary, blog, International Institute for Environment and Development, 10 July, 2014, http://www.iied.org/europes-controversial-ttip-treaty-good-bad-unnecessary, and Erixon, Fredrik, Trans-Atlantic Trade and Investment Partnership and the European Parliament, blog, VOX, 18 May, 2014, http://www.voxeu.org/article/trans-atlantic-trade-and-investment-partnership-and-european-parliament. 139 Further, as for "fair and equitable treatment", "[i]n EU agreements, the standard will set out precisely what elements are covered and thus prohibited". European Commission, Investment Protection and Investor-to-State Dispute Settlement in EU Agreements, Fact-Sheet, November 2013, p. 2, http://trade.ec.europa.eu/doclib/docs/2013/november/tradoc 151916.pdf.

140 Howse, note 68, p. 1.
} 
Ugandan Madhvani group to establish a sugar plantation, Amuru Sugar Works, requiring in total 40.000 hectares. For that purpose, the Amuru Land Board has allotted an initial 10.000 hectares of "public land" to Madhvani. The project is very controversial in the region and is being portrayed as a land grab that will result in the eviction of thousands of land users, who claim that the land had been unused only temporarily due to the war. Local leaders have challenged the land board's decision in court. In 2012, a ruling in the Gulu High Court endorsed the land board's decision, but the decision has been appealed to the Court of Appeals, where it is pending with an injunction against the defendants. ${ }^{141}$

In the other case, a German multinational named Neumann Kaffe Gruppe leased more than 2500 hectares in Western Uganda from the Ugandan Investment Authority, which had bought it from a private owner. According to NGO's, some 400 families, who had customary user rights, had been evicted from the land. ${ }^{142}$ Some of them sued Kaweri, the Ugandan government and the former landowner. In a remarkable judgment in 28 March 2013, the High Court ordered that compensation be paid, but not by Kaweri or the government but by the lawyers involved in the deal. In an obiter dictum, the Court remarked that the investors "should have respected the human rights and values of people and as honourable businessmen and investors they should have not moved into the lands unless they had satisfied themselves that the tenants were properly." ${ }^{143}$ The case has been appealed and is pending. The German embassy appears to have followed the case, but Germany has no BIT with Uganda.

It is not for me to determine the merits of the claims, although it is clear that the people concerned are in a very vulnerable position. I will just say a few words about how international law appears to have influenced the events.

These projects are broadly in line with the development policies advocated by

\footnotetext{
141 See Madhvani wins Amuru land case, New Vision, no date, http://www.newvision.co.ug/mobile/Detail.aspx?NewsID=628837\&CatID=395; Court of Appeal blocks Activity on Disputed Land in Amuru, Acholi Times, 15 October 2012

http://www.acholitimes.com/index.php/land-issues/928-court-of-appeal-blocks-activity-on-disputed-land-in-amuru

142 Kaweri: Kaffee mit dem Geschmack der Vertreibung, Fian Deutschland, no date, http://www.fian.de/fallarbeit/kaweriuganda/.

143 Baleke \& 4 Ors v Attorney General \& 2 Ors, Civil Suit No 179 of 2002, High Court of Uganda, Judgment 28 March 2013, para 107, http://www.ulii.org/ug/judgment/high-court/2013/65. See also De Schutter 2013, note 89, p. 7; Case Profile: Kaweri Coffee (part of Neumann Gruppe) lawsuit (re forced eviction in Uganda, Business and Human Rights, http://business-humanrights.org/en/kaweri-coffee-part-of-neumann-gruppe-lawsuit-re-forced-eviction-in-uganda\#c7 8428. The facts are disputed. For Neumann's version of the story, see Chronology of events, Kaweri Coffee Plantation 2000 to 2013, Neumann Grupppe GmbH, 16 April 2013, http://www.nkg.net/userfiles/Documents/2013-04-16 Chronologie - ENG.pdf. I believe that it is relevant to mention here that the judge, Anup Singh Choudry, is well-known and controversial in Uganda.)
} 
international financial institutions and donors for years, which call for increased productivity in agriculture and more focus on cash crops. ${ }^{144}$ More specifically, the Kaweri investment - which produces coffee for export -- was made possible by Uganda being linked to the international trading system through the WTO and the trade agreement with the EU. Another crucial condition was the liberalization of laws on export of capital (i.e., returns), which was supported by the IFIs, ${ }^{145}$ and which is broadly in line with BIT standards.

If any of the two investments had been covered by a BIT - like the agreement between Uganda and the UK - the investments would have been protected by such a treaty, and remedies by Ugandan courts might have been considered to constitute an expropriation or an "unequitable treatment", in violation of the treaty. ${ }^{146}$ The scope of action for the government - which is engaged in finding a solution to the Amuru dispute - would also have been reduced. However, since neither of these cases is covered by a BIT, there is more room for domestic legal and political action.

Has international law been useful for their struggle? If the people threatened by the Amuru Sugar Works or the people evicted at the Kaweri Coffee Plantation have been wronged, they could complain before a global or regional human rights institution. Since human rights complainants - in distinction to investors -must exhaust local remedies, that is not yet possible, because neither of the cases has run its full course in the Ugandan judicial system (for the Kaweri case that has taken more than a decade) ${ }^{147}$ Even if it would happen, it would not result in a binding and effective decision (except, in theory, in the African Court).

Nevertheless, international law came to play a role in the Kaweri case, and the Kaweri case came to play a role in the development of international law. The German branch of the NGO Fian, which collaborates with the Ugandan Wake up and Fight for Your Rights Madudu Group, has been quite vocal in Germany -- the home state of Neumann Kaffe Gruppe. Fian does not appear to have held the German government directly responsible, but the two organizations brought the matter to the German National Contact Point (NCP), which is a soft mechanism for complaints regarding the OECD Guidelines for multinational enterprises. The

\footnotetext{
144 See Uganda's Poverty Reduction Strategy Paper, May 2010, prepared in collaboration with the IMF, http://www.imf.org/external/pubs/ft/scr/2010/cr10141.pdf.

${ }_{145}$ Louis A. Kasekende, Capital Account Liberalisation: The Ugandan Experience, Development Policy Review, 2001, vol 19 , p. 101-120.

146 Obviously, this would apply more to Kaweri, which has already invested considerable sums.

147 Arguably, the victims could have had their complaints accepted as admissible due to the delays, which might constitute a denial of justice - a violation of human rights in itself.
} 
NCP found that Neumann had done nothing wrong. ${ }^{148}$ However, both the present and the former UN rapporteur on the right to food have been engaged in the Kaweri case. ${ }^{149}$ Even more interestingly, in its concluding observations on the latest German implementation report on the International Covenant on Civil and Political Rights, the Human Rights Committee noted the following with regard to the Kaweri case: ${ }^{150}$

The State party is encouraged to set out clearly the expectation that all business enterprises domiciled in its territory and/or its jurisdiction respect human rights standards in accordance with the Covenant throughout their operations. It is also encouraged to take appropriate measures to strengthen the remedies provided to protect people who have been victims of activities of such business enterprises operating abroad.

The Committee did not couch this in terms of legal obligations. However, the mere mentioning of the case in this context is a step in the build-up of what might become a legal obligation of states to ensure that their corporations observe human rights standards in foreign lands. ${ }^{151}$

\section{Final words}

We think of international law as a set of rules for the common good and to protect the weak against the strong. International law provides rules and mechanisms that safeguard the sovereignty even of small states and the human rights even of the little people. International law further creates procedures for states to cooperate in order to protect the environment or to promote economic development. However, international law also enables large transfer of wealth from the poor to the rich, for instance by maintaining relations of dependence through the international trade regime, ${ }^{152}$ or by incentivizing and enabling a land grab. Most of all, international law as a legal system and a legal practice

\footnotetext{
148 Final declaration by the National Contact Point for the OECD Guidelines for Multinational Enterprises regarding a complaint by Wake up and Fight for Your Rights Madudu Group and FIAN Deutschland against Neumann Gruppe GmbH, 30 March 2011, http://www.oecd.org/investment/mne/48755179.pdf.

149 See note 143.

150 Human Rights Committee, Concluding observations on the sixth periodic report of Germany, adopted by the Committee at its 106th session (15 October - 2 November 2012), CCPR/C/DEU/CO/6, p 4.

151 This passage echoes principles 2 and 25 of the Guiding Principles on Bisuness and Human Rights. Report of the Special Representative of the Secretary-General on the issue of human rights and transnational corporations and other business enterprises, John Ruggie: Guiding Principles on Business and Human Rights: Implementing the United Nations "Protect, Respect and Remedy" Framework, 21 March 2011, A/HRC/17/31.

152 Cf De Schutter, Olivier, International Trade in Agriculture and the Right to Food in De Schutter, O and Cordes, KY (eds), Accounting for Hunger: The Right to Food in the Era of Globalisation, Hart Publishing, 2011, p. 137, 145 and 175.
} 
privileges certain interests and leave others unattended. While this may be a result intended by some parties, it is irrational from the perspective of the proclaimed, common goal of the international community, that "[e]veryone is entitled to a social and international order in which the rights and freedoms set forth in this Declaration can be fully realized". ${ }^{153}$ But international law is made and used -- not only by great powers and economic interests but also by NGOs, social movements, philosophers and ordinary people. ${ }^{154}$

${ }_{153}$ Article 28 of the Universal Declaration on Human Rights. Cf Feyter, Koen De, Human Rights: Social Justice in the Age of the Market (Zed Books, London and New York, 2005) 23. This would mean that all human rights are jus cogens. An alternative argument would be that human rights are rights of third parties, meaning that states cannot dispose of these rights, and cannot limit them through treaty obligations, be they bilateral or multilateral.

154 On the uses of international law, see Rajagopal, Balakrishnan, The Role of Law in Counter-hegemonic Globalization and Global Legal Pluralism: Lessons from the Narmada Valley Struggle in India, Leiden Journal of International Law, volume 18, p 345-387, at 384-387. 